\title{
Climate-induced changes in the North Sea Decapoda over the last 60 years
}

\author{
John A. Lindley ${ }^{1}$, Richard R. Kirby ${ }^{2, *}$ \\ ${ }^{1}$ Sir Alister Hardy Foundation for Ocean Science, Citadel Hill, The Hoe, Plymouth PL1 2PB, UK \\ ${ }^{2}$ University of Plymouth, School of Marine Science and Engineering, Drake Circus, Plymouth PL4 8AA, UK
}

\begin{abstract}
In the mid-1980s the North Sea ecosystem experienced a climate-induced regime shift that has favoured decapods and detritivores in the benthos and jellyfish in the plankton over commercial fisheries. Here, we investigate changes among the Decapoda in the North Sea plankton over the last 60 yr. Decapods are important predators in the plankton and the benthos where they can influence productivity and structure communities. In the North Sea it has been suggested that a climate-driven increase in decapod abundance has been important in propagating the climate signal through the North Sea food web. We show that climate-induced changes in the Decapoda in the central and southern North Sea include the presence of new warm-water taxa, changes in the abundance and proportions of commercial species of shrimp, and an earlier occurrence of decapod larvae in the plankton compared with the period 1981-1983. Notable amongst the warm-water taxa appearing in the North Sea is the predatory swimming crab Polybius henslowii that can swarm in large numbers when conditions are favourable and that is known to exhibit range shifts in response to fluctuations in hydroclimatic forcing. We suggest that climate-induced changes among North Sea decapods have played an important role in the trophic amplification of a climate signal and the development of the new North Sea dynamic regime. Understanding these changes is likely to be imperative for a successful ecosystem-based approach to the future management of North Sea fisheries at a time of climate change.
\end{abstract}

KEY WORDS: Benthos · Plankton · Polybius henslowii $\cdot$ Phenology $\cdot$ Temperature

\section{INTRODUCTION}

Ecosystems can alternate suddenly between contrasting persistent states due to internal processes or external drivers. In the marine environment, overfishing (top-down control) and hydroclimatic change (bottomup control) have been held responsible for abrupt changes in the trophodynamics and community structure of several marine ecosystems (Pauly et al. 1998, Oguz 2007, Österblom et al. 2007, Beaugrand et al. 2008, Kirby \& Beaugrand 2009). In some cases, the combined effects of fishing and climate may have acted synergistically to drive marine ecosystems rapidly towards new dynamic regimes (Kirby et al. 2009).

A common outcome of biological change in 2 marine ecosystems that have been fished heavily for
Atlantic cod Gadus morhua-the eastern Scotian Shelf and the North Sea - has been an increase in the number of decapods. This has been observed in their benthic abundance in the eastern Scotian Shelf (Frank et al. 2005) and in their planktonic larval abundance in the North Sea (Kirby et al. 2008). In both ecosystems, the decline in abundance of cod, which is an important top predator of decapods, has been held partly responsible for the increase in abundance of decapods (Frank et al. 2005, Kirby et al. 2009). In the North Sea, however, decapod larval abundance in the plankton also correlates positively with changes in sea surface temperature, which has warmed by $1^{\circ} \mathrm{C}$ since the mid-1980s (Kirby et al. 2008), and so, the increase in decapods here also appears to have been driven by climate. 
The increase in decapod larvae in the North Sea plankton coincides with a change in holozooplankton composition and a decline in the larval abundance of benthic bivalves as well as a decline in the numbers of plaice Pleuronectes platessa and sole Solea solea recruits (Kirby \& Beaugrand 2009), which along with other changes in the North Sea ecosystem comprise a climate-driven ecosystem regime shift that occurred during the 1980s (Beaugrand et al. 2008). While many of the recent changes in the North Sea ecosystem appear to be driven directly by temperature, we have suggested that some climate effects are mediated indirectly through linkages in the food web, in particular by top-down control by decapods (Kirby \& Beaugrand 2009). For example, decapod larvae can influence plankton community structure through predation on other zooplankton (Frank et al. 2005, Signa et al. 2008), and adult decapods can influence benthic communities and fisheries through the effects of their predation on bivalve and flatfish recruits (Barkai \& McQuaid 1988, van der Veer \& Bergman 1987).

The changes in the Decapoda in the plankton of the North Sea have been observed in continuous plankton recorder (CPR) samples (Kirby et al. 2008). Unfortunately, decapods (with the exception of sergestids, which rarely occur in the North Sea) are recorded only at that taxonomic level in routine analysis of CPR samples. Although occasional analyses to finer taxomomic levels have been conducted for the late 1940s and early 1950s (Rees 1952, 1955), for the period 19811983 (Lindley 1987) and for 1989 (Lindley et al. 1993), there is insufficient taxonomic resolution to understand what could be one of the most important of the changes in the biota comprising the North Sea regime shift. Therefore, we have re-examined CPR samples taken in the North Sea in 2008 to identify the Decapoda, where practical, to species or genus level to examine changes in both their abundance and seasonality. Since the larval identification of the most abundant decapods in CPR samples, the Polybiinae (swimming crabs), is impractical using morphological criteria, we applied a molecular approach for this group similar to that used previously to determine the effect of climate on echinoderm larvae in North Sea CPR samples (Kirby et al. 2007).

\section{MATERIALS AND METHODS}

\subsection{Plankton data}

Data on decapod larvae were collected by the CPR survey, which has operated in the North Sea on a routine monthly basis since 1946. Seawater enters the CPR through a front aperture and the plankton are retained on a moving band of silk gauze of mesh size $270 \mu \mathrm{m}$ that is slowly wound into a tank of formalin. In the laboratory the silk gauze is cut into sections (a CPR sample), each representing the plankton from $3 \mathrm{~m}^{3}$ of water taken over $10 \mathrm{n}$ miles $(18 \mathrm{~km})$ of tow at an average depth of $7 \mathrm{~m}$. The methods of CPR sampling and analysis have remained consistent throughout the time series (Batten et al. 2003).

North Sea CPR samples in which decapods were recorded in 2008 were re-examined and the Decapoda were extracted and identified to the finest taxonomic resolution possible based on morphological criteria as described by Lindley (1987). Swimming crab (Polybiinae) larvae that cannot be identified practicably to species level by morphological criteria in CPR samples, were identified by genetic analysis (see below).

\subsection{Genetic identification of Polybiinae larvae}

To identify larval Polybiinae in CPR samples a reference DNA sequence database was first constructed from adult representatives of the most common Polybiinae found in coastal waters around the UK; these were Liocarcinus arcuatus, L. corrugatus, L. depurator, L. holsatus, L. marmoreus, L. pusillus, Macropipus tuberculatus, Necora puber and Polybius henslowii. Adult Polybiinae were collected during benthic surveys and a single limb was preserved in ethanol from which total DNA was extracted using a standard SDS-proteinase-K, phenolchloroform protocol. Partial sequences of mitochondrial 16S rDNA were then amplified from the extracted DNA using the universal PCR primers 16sar-L and 16sbr-H (Palumbi et al. 1991) and the amplification products were sequenced on both strands (Genbank accession nos. GQ268539-GQ268547). Total DNA was then extracted from 48 individual larval Polybiinae collected by the CPR in 2008 using a standard protocol developed for this formalin-fixed tissue (Kirby et al. 2006). A partial mtDNA 16S rDNA gene sequence was then amplified using the PCR primers described above and sequenced on a single strand using the forward amplification primer as the sequencing primer. The identities of individual larvae were then determined by comparison to the adult DNA sequence database.

\subsection{Statistical methods}

The mean number for each taxon per sample in each month were determined for $1^{\circ}$ latitude $\times 2^{\circ}$ longitude rectangles and these values were then used to calculate an index of abundance for 6 standard areas of the North Sea (Fig. 1). Annual mean abundance (mean of monthly values) and the timing of the seasonal peak, 


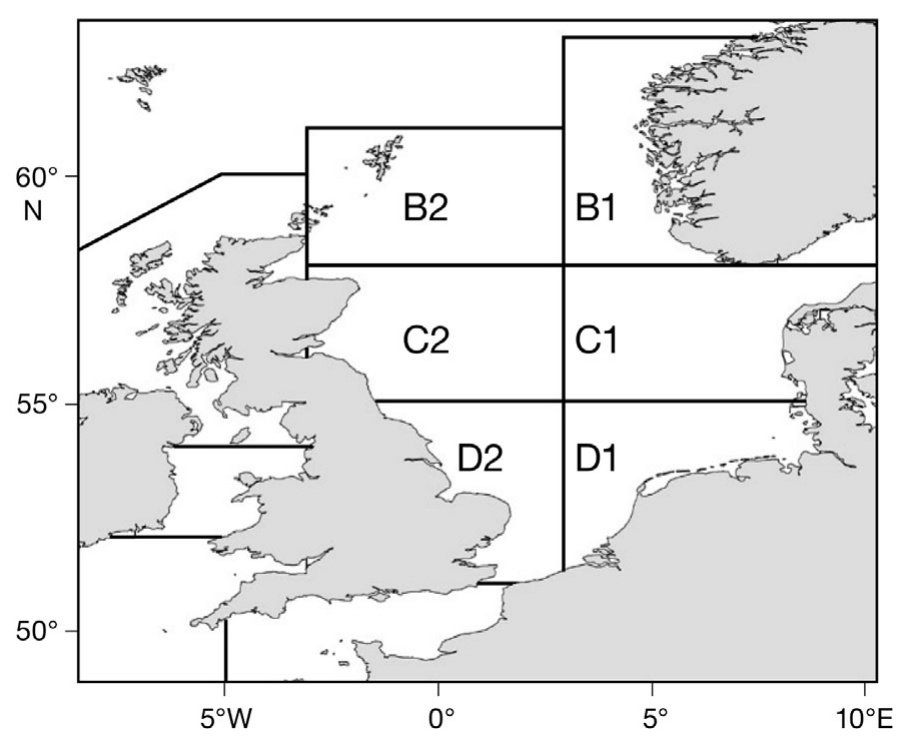

Fig. 1. Standard areas for North Sea continuous plankton recorder (CPR) data collection

and their SD values, were then calculated by the formulae defined by Colebrook \& Robinson (1965). Annual mean abundance $A$ was calculated by means of the formula:

$$
A=\frac{\sum_{m=1}^{12} x_{m}}{12}
$$

where $x_{m}$ is the mean abundance in month $m$ (i.e. January, $m=1$; February, $m=2 ; \ldots$; December, $m=12$ ). The SD values were calculated from the deviations of each monthly mean from $A$. Paired $t$-tests were used to determine the significance of differences in abundance, pairing the monthly values for each period. The timing of the seasonal peak (the central tendency, $T$ ) was calculated as a mean month coordinate weighted by monthly mean abundance (i.e. the centre of gravity; Colebrook \& Robinson 1965, Colebrook 1979, Edwards $\&$ Richardson 2004) as follows:

$$
T=\frac{\sum_{m=1}^{12} m \cdot X_{m}}{\sum_{m=1}^{12} X_{m}}
$$

where $x_{m}$ is the mean abundance in month $m$ (as described above for $m$ ). The central tendency $T$ is sensitive to changes in the timing of the seasonal cycle, the standard deviation $\sigma$ of the central tendency $T$ was calculated using the equation:

$$
\sigma=\sqrt{\frac{\sum_{m=1}^{12} x_{m}(m-T)^{2}}{\sum_{m=1}^{12} X_{m}}}
$$

where $x_{m}=$ mean abundance in month $m$ (as described above). The significance of the differences in timing in different periods was calculated using values of $T$ and $\sigma$ in 2-sample t-tests.
Data are presented for area B2, which is influenced strongly by Atlantic Ocean inflow around the north of Scotland, and for the average of the 5 remaining areas as previously described (Lindley 1987, Lindley et al. 1993). These results were compared with results from Rees (1952, 1955), Lindley (1987) and Lindley et al. (1993). While the timing of occurrence of the taxa in Rees $(1952,1955)$ is generally consistent with the results from 1981-1983 (Lindley 1987), detailed analysis of these data have not been included here as the samples examined were selected based on slightly different criteria in some years (Rees 1955).

\section{RESULTS}

The most abundant taxa identified in the analysis of the 2008 CPR samples were the Polybiinae, Upogebia deltaura and Callianassa subterranea constituting 37.4, 33.5 and $5.9 \%$ of the total decapods, respectively; these were also the most abundant species in Rees' studies from 1947 to 1951 (Rees 1955). To facilitate comparisons with previous studies, Fig. 2 shows the percentages given in Rees (1955, their Fig. 5) with equivalent data from 1981-1983, 1989 and 2008. In addition to the 3 taxa already mentioned, Corystes cassivelaunus comprised 5.4, 1.9 and $7.4 \%$, and Atelecyclus rotundatus comprised 3.9, 1.8 and $1.0 \%$ in 1981-1983, 1989 and 2008, respectively. The mud shrimp C. subterranea was the only taxon recorded in area B2 that was less abundant in 2008 than in 1981-1983, in contrast with Polybiinae and Pisidia longicornis, which were both much more abundant in 2008 (Table 1). Both the Polybiinae and $P$. longicornis were more abundant in the rest of

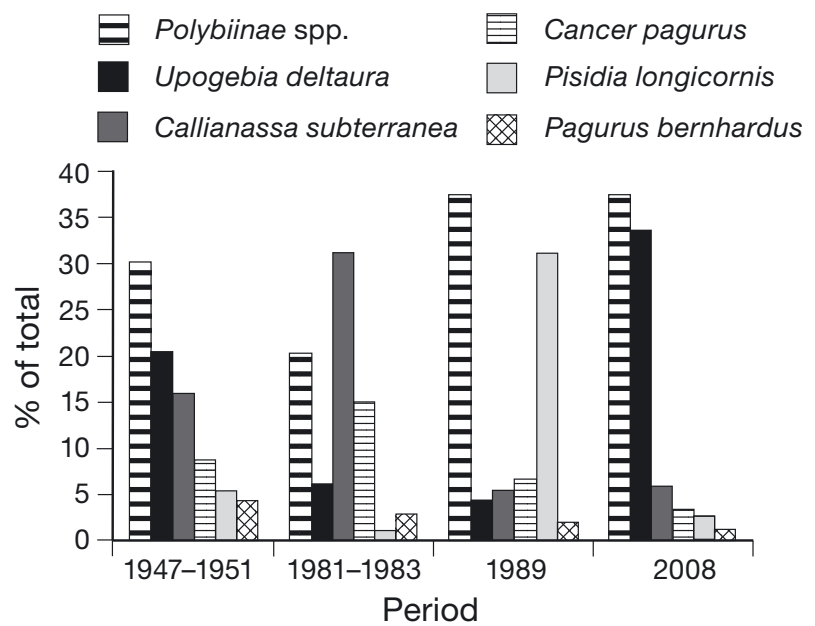

Fig. 2. Percentages of total Polybiinae, Upogebia deltaura, Callianassa subterranea, Cancer pagurus, Pisidia longicornis and Pagurus bernhardus in CPR samples in 1947-1951, 1981-1983, 1989 and 2008 
Table 1. Mean numbers of larval decapods per CPR sample for the 9 most abundant decapod taxa in 1981-1983, 1989 and 2008 ranked in descending order of their abundance in areas B1, C1, C2, D1 and D2 in 2008

\begin{tabular}{|lccccccc|}
\hline \multirow{2}{*}{ Species } & \multicolumn{7}{c|}{ Abundance } \\
\cline { 2 - 8 } & \multicolumn{3}{c}{ Area B2 } & \multicolumn{4}{c}{ Areas B1, C1, C2, D1, D2 } \\
& $1981-1983$ & 1989 & 2008 & $1981-1983$ & 1989 & 2008 \\
\hline Polybiinae spp. & 0.07 & 0.15 & 2.06 & 0.69 & 2.59 & 1.67 \\
Upogebia deltaura & $<0.005$ & 0.00 & 0.01 & 0.33 & 0.45 & 1.27 \\
Callianassa subterranea & 0.16 & 0.04 & 0.06 & 1.42 & 0.35 & 0.30 \\
Corystes cassivelaunus & 0.00 & 0.00 & 0.00 & 0.23 & 0.10 & 0.28 \\
Pisidia longicornis & $<0.005$ & 0.00 & 0.83 & 0.05 & 1.67 & 0.20 \\
Cancer pagurus & 0.28 & 0.22 & 0.36 & 0.67 & 0.40 & 0.11 \\
Pagurus bernhardus & 0.02 & 0.08 & 0.20 & 0.04 & 0.11 & 0.04 \\
Atelecyclus rotundatus & 0.16 & 0.17 & 0.19 & 0.02 & 0.09 & 0.01 \\
Hyas coarctatus & 0.02 & 0.06 & 0.24 & 0.04 & 0.04 & 0.01 \\
\hline
\end{tabular}

Table 2. Seasonal and geographical distributions, and specific identities of the 48 Polybiinae larvae sampled by the CPR in the North Sea in 2008 in areas B1, B2, C1, C2, D1 and D2 and identified by genetic analysis (values indicate no. of ind.). No value, and months that are not represented, indicate zero ind.

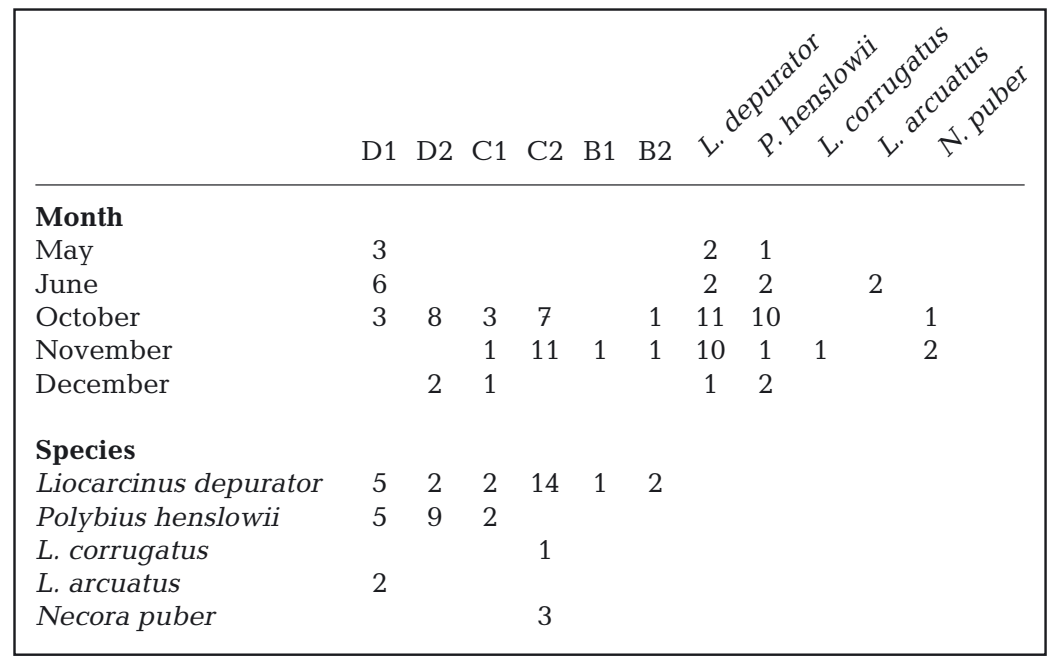

by species, month and area in Table 2 ; of particular note is the occurrence of Polybius henslowii, which was unknown in the North Sea at the time of earlier studies. We also found Goneplax rhomboides in our North Sea samples for the first time. The mud shrimp Pesterella tyrrhena (= Callianassa tyrrhena) and the thumb-nail crab Thia scutellata were more abundant and widespread than in previous studies, when they only occurred in small numbers in the southern North Sea. Locations of $P$. henslowii, $G$. rhomboides, P. tyrrhena and T. scutellata are shown in Fig. 3a-d. Although less numerous in the CPR record from the North Sea than other Decapoda analysed in this study, the changes in the abundance and proportion of species of the commercially important Crangonidae (brown shrimps) in the survey are given for all areas combined in Table 3.

When we examined seasonality we found that Hyas coarctatus has consistently been among the earliest of the decapods to appear in the year (Fig. 4). In the North Sea, except for area B2, all 9 taxa recorded in Table 1 occurred later in the year in 1981-1983 than in the more recent studies (mean advance from 1981-1983 of $35 \mathrm{~d}$, [ $\sigma=16 \mathrm{~d}$ ] in 1989 , and $48 \mathrm{~d}[\sigma=20 \mathrm{~d}]$ in 2008), and only $H$. coarctatus and the Polybiinae were later-appearing in 2008 than in 1989 (by 2 and 4 d, respectively) (Fig. 4). Table 4 shows that in areas B1, C1, C2, D1 and D2, the year 2008 was the North Sea in 1989 than in 2008 and only Callianassa subterranea and Cancer pagurus were most abundant in 1981-1983 (Table 1). Unfortunately, due to the restricted number of months of occurrence of most species in the plankton, the SDs exceeded the annual means in nearly all cases. The only statistically significant differences we found were between the maximum abundance of Pagurus bernhardus in the North Sea in 1989 (excluding area B2 in 1989) and their abundance in 1981-1983 and 2008. However, in the context of the increase in total decapod larvae (Kirby et al. 2008), the fact that most of the maxima occur in 1989 or 2008 provides convincing evidence that the increase is spread across a broad range of taxa.

The composition of Polybiinae larvae identified by the molecular analysis of CPR samples are tabulated largely consistent with 1989, with significant to very significant advances in timing from 1981-1983 across most taxa while changes in B2 were less significant among time periods. In area B2, Corystes cassivelaunus was absent and of the remaining 8 taxa, Pisidia longicornis and Upogebia deltaura were absent in 1989 and rare (mean abundance $<0.005$ ind. sample ${ }^{-1}$ ) in 1981-1983. Five taxa occurred later in area B2 in 1981-1983 than in other years and 5 occurred earliest in 1989; mean advance from 1981-1983 of $36 \mathrm{~d}(\sigma=30$ d) in 1989 and $15 \mathrm{~d}(\sigma=18 \mathrm{~d})$ in 2008. Only Callianassa subterranea occurred later in 1989 than 1981-1983 (by $6 \mathrm{~d}$ ) and $H$. coarctatus and $U$. deltaura occurred later in 2008 than in 1981-1983 (by 7 and 11 d, respectively). These 3 species were only present in small numbers (Table 1). 

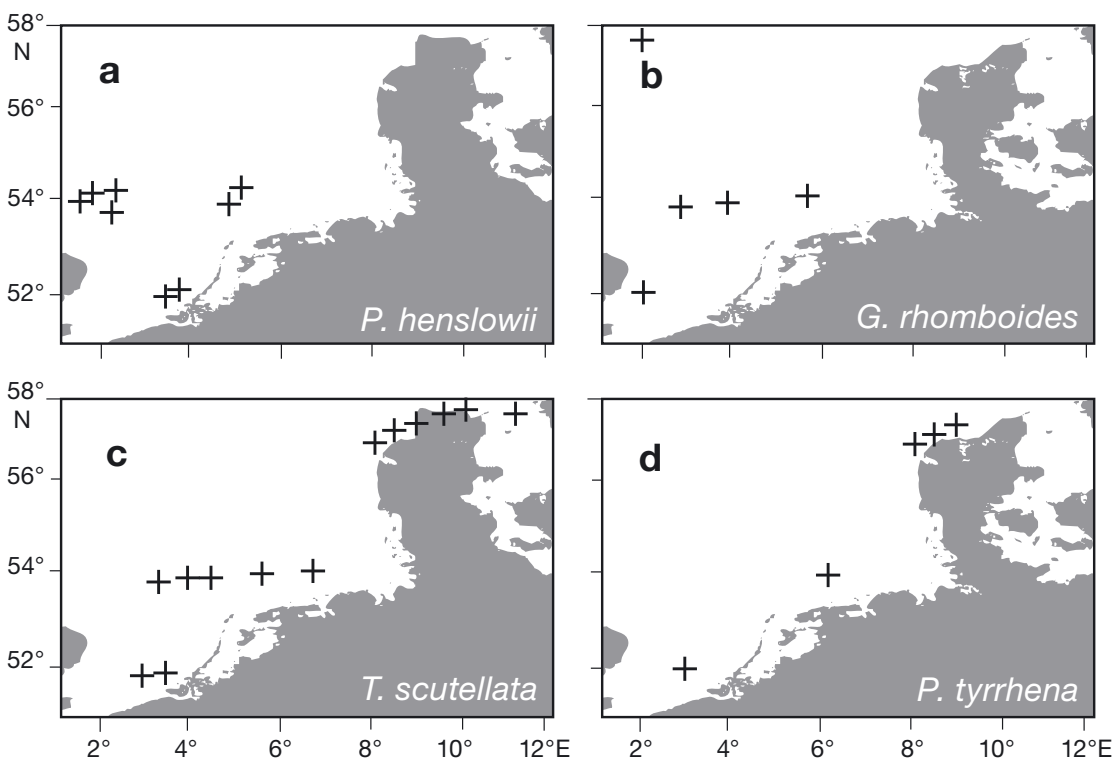

Fig. 3. The distributions of records of (a) Polybius henslowii, (b) Goneplax rhomboides, (c) Thia scutellata and (d) Pestarella tyrrhena in CPR samples collected in the North Sea in 2008
Fjord (Berggren 2008). The records of 2 further species, the mud shrimp Pesterella tyrrhena and the thumbnail crab Thia scutellata in CPR samples in 2008 are also noteworthy due to an increase in their spatial extent. The former was recorded only in small numbers in the Southern Bight in the late 1940s and early 1950s (Rees 1952, 1955) and 1989 (J. A. Lindley unpubl. data) and was absent from CPR records in the North Sea between 1981 and 1983 (Lindley 1987). In 2008, in the present study, we found P. tyrrhena off the coast of northern Denmark in July as well as farther south in the North Sea in August. Similarly, records of $T$. scutellata were limited to the southern North Sea in studies by Rees (1952, 1955) and Lindley (1987, J. A. Lindley unpubl. data from 1989) but occurred off the coast of Denmark
Table 3. Crangonidae in CPR records: total numbers for 1981-1983 and 1989 and 2008

\begin{tabular}{|lccc|}
\hline & Period & \multicolumn{2}{c|}{ Year } \\
\cline { 3 - 4 } & 1981-1983 & 1989 & 2008 \\
\hline Crangon allmanni & 51 & 15 & 7 \\
C. crangon & 12 & 17 & 43 \\
Philocheras bispinosus & 14 & 22 & 29 \\
P. fasciatus & 1 & 0 & 0 \\
P. trispinosus & 2 & 15 & 3 \\
Pontophilus norvegicus & 1 & 0 & 0 \\
Unidentified & 1 & 1 & 0 \\
\hline
\end{tabular}

\section{DISCUSSION}

The most notable changes in the North Sea Decapoda sampled by the CPR over the last $60 \mathrm{yr}$ is an advance in the timing of their occurrence in the plankton of the central and southern North Sea (Fig. 4b), and the appearance of the warm-water taxa Polybius henslowii and Goneplax rhomboides (Fig. 3a,b). The swimming crab $P$. henslowii was not recorded previously in the North Sea except for the Shetland Islands area before the 1980s (Ingle 1980) and only exceptionally east of Scotland and off the coast of southern Norway (d'Udekem d'Acoz 1999). The angular crab G. rhomboides was not known in the North Sea according to Ingle (1980), although Moore (1986) did report a recording off Northumberland in 1963, and the species has been recorded recently in Swedish waters in the stomach contents of a cod caught outside the estuary of Gullmar
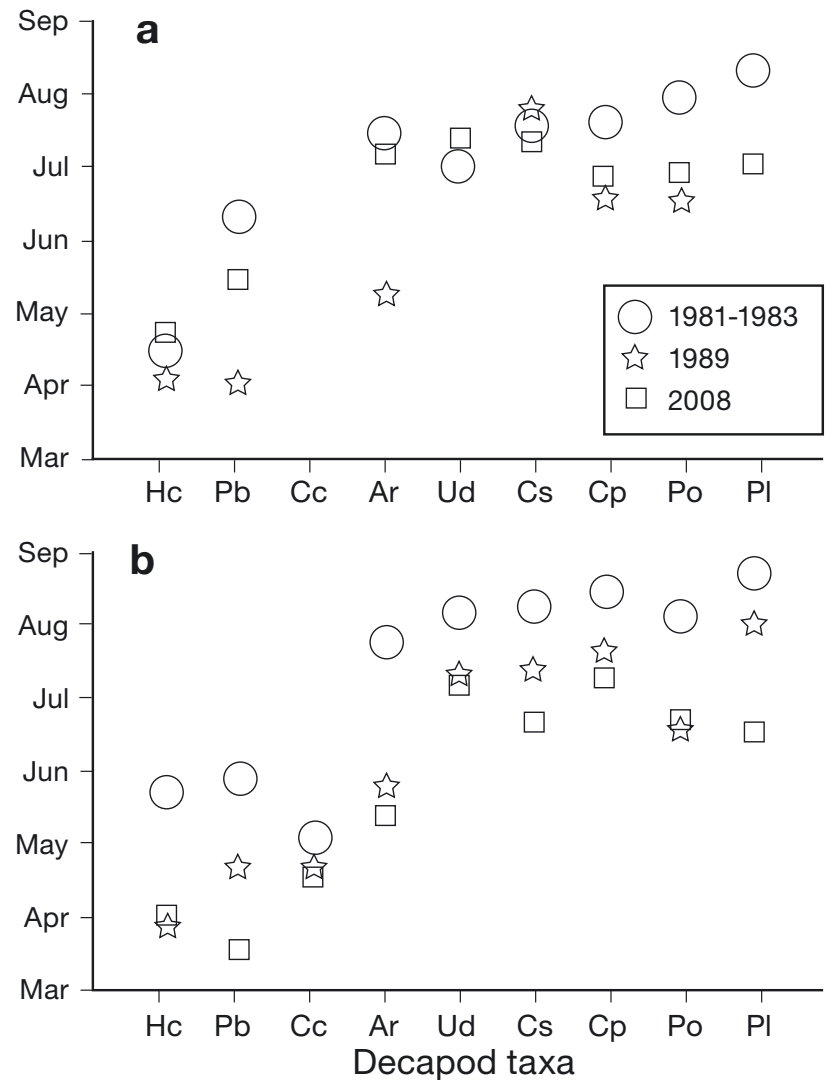

Fig. 4. Mean time of occurrence of decapod taxa in (a) Area B2 and Areas B1, C1, C2, D1 and D2 in the North Sea during 19811983, in 1989 and in 2008. Hc: Hyas coarctatus; Pb: Pagurus bernhardus; Cc: Corystes cassivelaunus; Ar: Atelecyclus rotundatus; Ud: Upogebia deltaura; Cs: Callianassa subterranean; Cp: Cancer pagurus; Po: Polybiinae; Pl: Pisidia longicornis 
Table 4. Significant differences in the seasonal timing of decapod taxa in the plankton between time periods. ${ }^{*} 0.05>\mathrm{p}>0.01,{ }^{* *} 0.01>\mathrm{p}>0.001,{ }^{* * *} \mathrm{p}<0.001$; ns: not significant; nd: no data or data insufficient (comparison results in the same format for 1981-1983 with 1989 are given in Table III in Lindley et al. 1993)

\begin{tabular}{|c|c|c|c|c|c|c|}
\hline Species & $\begin{array}{c}1981-83 \\
\& 1989\end{array}$ & $\begin{array}{c}\text { Area B2 } \\
1981-83 \\
\& 2008\end{array}$ & $\begin{array}{c}1989 \\
\& 2008\end{array}$ & $\begin{array}{c}\text { Areas B1 } \\
1981-83 \\
\& 1989\end{array}$ & $\begin{array}{c}\mathrm{C} 1, \mathrm{C} 2, \\
1981-83 \\
\& 2008\end{array}$ & $\begin{array}{c}\text { D1, D2 } \\
1989 \\
\& 2008\end{array}$ \\
\hline Polybiinae spp. & $*$ & $* *$ & ns & $* *$ & $* *$ & ns \\
\hline Upogebia deltaura & nd & ${ }^{*}$ & nd & $* *$ & $* * *$ & ns \\
\hline Callianassa subterranea & ns & ns & ns & $*$ & $* * *$ & ns \\
\hline Corystes cassivelaunus & nd & ns & nd & ns & ns & ns \\
\hline Pisidia longicornis & nd & *** & nd & ${ }^{*}$ & $* * *$ & *** \\
\hline Cancer pagurus & ${ }^{*}$ & ns & ns & $* *$ & ${ }^{* *}$ & ns \\
\hline Pagurus bernhardus & nd & nd & ns & ns & $*$ & ns \\
\hline Atelecyclus rotundatus & nd & ns & nd & ns & ns & ns \\
\hline Hyas coarctatus & $* * *$ & ns & $* * *$ & ${ }^{*}$ & ${ }^{* *}$ & ns \\
\hline
\end{tabular}

haps not surprising that phenological changes are less apparent: (1) it is warmer in winter than the rest of the North Sea (Kirby et al. 2007) and (2) the composition and phenology of the plankton is strongly influenced by advection.

Although the relationship between larval abundance and the size of benthic populations has not been generally established for invertebrate macrofauna, larval surveys are a longestablished means of estimating the spawning stocks of decapods (Briggs et al. 2002). While Pandalus and $\mathrm{Ne}$ phrops are sampled poorly by the CPR, fisheries data - which show that landings of these predatory species (ICES

in July and August and farther south in August and September. Both P. tyrrhena and T. scutellata are warm-water taxa, as are P. henslowii and G. rhomboides, and so, while we cannot exclude the possibility that rare taxa were missed in earlier studies, our results appear to indicate an increase in abundance and range of warm-water decapods in the North Sea.

Temperature is known to influence the seasonality of the North Sea plankton, particularly the meroplankton (Edwards \& Richardson 2004) and the benthic biota, the latter especially in the colder southern North Sea (Neumann et al. 2009b). Our new data on the timing of occurrence of decapod larvae in CPR samples are based only upon the single year 2008, so they should be treated with some caution as they may not be fully representative. Nevertheless, there appears to be a large seasonal advance in areas B1, C1, C2, D1 and D2 in which all 9 recorded decapod taxa appeared in the plankton earlier in the year in 2008 than in either 1981-1983 (Fig. 4b, Table 4) or earlier studies (Rees $1952,1955)$. These changes are comparable with the results for 1989, which at the time was considered to have been an exceptionally warm year (Lindley et al. 1993). Areas B1, C1, C2, D1 and D2 include the shallower southern North Sea and German Bight, the coldest areas of the North Sea in winter (Lee \& Ramster 1981), which are both now warmer in winter than prior to the North Sea regime shift (Kirby et al. 2007). The phenological changes occurring among the decapod larvae, which reflect similar changes in other zooplankton and phytoplankton taxa (Edwards \& Richardson 2004), appear to correlate with the appearance of warmer temperatures earlier in the year (Kirby et al. 2007). In contrast, we found smaller changes in seasonality among the Decapoda in area B2 (Fig. 4a, Table 4); this northwestern region of the North Sea is influenced by Atlantic Ocean inflow and so for 2 reasons, it is per-
2006) and Cancer (Heath 2005) have increased markedly in the North Sea - are consistent with a general increase in decapod larval abundance (Kirby et al. 2008), which may be indicative of changes in the North Sea benthos. Similarly, Rees et al. (2007) noted increases in the abundance of mud shrimps in the benthos in parts of the North Sea. An established relationship between temperature and the abundance of benthic invertebrates in the southern North Sea (Neumann et al. 2008) also agrees with our findings on larval abundance (Kirby et al. 2008). However, the appearance of a similar relationship elsewhere may be influenced by regional hydrographical conditions such as stratification (Neumann et al. 2009a), which can also influence the vertical distribution of larvae (Lindley et al. 1994) with effects on the results of single depth sampling with the CPR.

Several studies have now described pronounced and sustained responses of marine ecosystems to climate warming (Intergovernmental Panel on Climate Change WGII 2007). Based upon studies of the North Sea plankton during the regime shift we recently proposed a new mechanism for regime change, which we called trophic amplification, where linkages in the food web acted to amplify a climate signal leading rapidly to a new dynamic regime (Kirby \& Beaugrand 2009). Changes observed in the North Sea plankton after the ecosystem shift were an increase in microalgae (Reid et al. 1998), a change in the composition and abundance of the holozooplankton (Beaugrand et al. 2008), increases in the frequency of jellyfish and in the abundance of decapod and echinoderm larvae, and a decrease in bivalve larvae and flatfish recruits (Kirby \& Beaugrand 2009).

In the eastern Scotian Shelf and the northeast Newfoundland Shelf an increased abundance of decapods in the plankton and benthos has been associated with a 
reduction in predation pressure from cod (Lilly et al. 2000, Frank et al. 2005); adult cod feed on crabs and other small crustaceans (Smith et al. 2007) and are known to exert top-down control of benthic decapod abundance (Worm \& Myers 2003). Evidence from the Norwegian Skagerrak indicates that large cod $>15 \mathrm{~cm}$ in length feed mainly on caridean shrimp, anomuran and brachyuran crabs and fish (Hop et al. 1992) and so the decline in North Sea cod could have led to some of the changes we have observed among the North Sea Decapoda. However, we have previously shown that temperature and phytoplankton abundance, which have both increased in the North Sea since the mid1980 s, also influence decapod abundance positively (Kirby et al. 2008). This present study reveals that a component of the climate-induced increase in the abundance of the North Sea Decapoda is an increased abundance and spatial extent of warm-water taxa. In this regard, the occurrence of the opportunistic carnivore, Polybius henslowii, is especially notable. Although it is a benthic species, $P$. henslowii has periodic pelagic phases, which is unusual for crabs, and it can swarm in large numbers when conditions are favourable, exhibiting shifts in its range in response to fluctuations in hydroclimatic forcing (Signa et al. 2008).

We have argued that decapods are an important trophic group in propagating the hydroclimatic signal through the North Sea food web by their top-down effects (Kirby \& Beaugrand 2009). For example, an increase in decapod abundance could explain a steady decline in bivalve larval abundance after the end of the 1990s, despite the fact that the larval abundance of both taxa correlates positively with sea surface temperature (Kirby \& Beaugrand 2009). The presence of new warm-water decapod taxa in the North Sea may, therefore, be an important component of the trophic amplification of the climate signal. In this respect, the increased abundance and proportion of Crangonidae in the plankton since the 1980s is also noteworthy (Table 3); these commercially important brown shrimps are important predators of small bivalves and the juveniles of larger bivalve species (Beukema \& Dekker 2005).

In addition to being important predators of bivalves, predation by adult decapods on the seabed may have also contributed to the decline of flatfish recruits, and predation by decapod larvae in the plankton (Signa et al. 2008) may have contributed to changes in the North Sea holozooplankton (Kirby \& Beaugrand 2009) that underpins fish recruitment (Beaugrand et al. 2003). In this way, the synergistic effects of fishing and climate on the abundance and composition of the decapod fauna of the North Sea may have profound ecological and socioeconomic effects. Appreciating the interaction between fishing and climate on the food web is likely to prove imperative for the successful application of an ecosystem-based approach to the management of North Sea fisheries, especially at a time of climate change.

\section{LITERATURE CITED}

Barkai A, McQuaid C (1988) Predator-prey role reversal in a marine benthic ecosystem. Science 242:62-64

Batten SD, Clark R, Flinkman J, Hays G and others (2003) CPR sampling: the technical background, materials and methods, consistency and comparability. Prog Oceanogr 58:193-215

> Beaugrand G, Brander KM, Lindley JA, Souissi S, Reid PC (2003) Plankton effect on cod recruitment in the North Sea. Nature 426:661-664

Beaugrand G, Edwards M, Brander K, Luczak C, Ibanez F (2008) Causes and projections of abrupt climate-driven ecosystem shifts in the North Atlantic. Ecol Lett 11:1157-1168

Berggren M (2008) New crab found in Swedish waters. University of Gothenburg News Archive, Gothenburg

Beukema JJ, Dekker R (2005) Decline of recruitment success in cockles and other bivalves in the Wadden Sea: possible role of climate change, predation on postlarvae and fisheries. Mar Ecol Prog Ser 287:149-167

Briggs RP, Armstrong MJ, Dickey-Collas $M$, Allen $M$, McQuaid N, Whitmore J (2002) The application of fecundity estimates to determine the spawning stock biomass of Irish Sea Nephrops norvegicus (L.) using the annual larval production method. ICES J Mar Sci 59:109-119

Colebrook JM (1979) Continuous plankton records: seasonal cycles of phytoplankton and copepods in the north Atlantic Ocean and the North Sea. Mar Biol 51:23-32

Colebrook JM, Robinson GA (1965) Continuous plankton records: seasonal cycles of phytoplankton and copepods in the north-eastern Atlantic and the North Sea. Bull Mar Ecol 6:123-139

d'Udekem d'Acoz C (1999) Inventaire et distribution des Crustacés Décapodes de l'Atlantique nord-orientale, de la Mediterranée et des eaux continentales adjacent au nord de $25^{\circ} \mathrm{N}$. Patrimoines naturels (MNHN/SPN CPN) 40. Publications Scientifiques du Muséum, Paris

Edwards M, Richardson AJ (2004) Impact of climate change on marine pelagic phenology and trophic mismatch. Nature 430:881-883

> Frank KT, Petrie B, Choi JS, Leggett WC (2005) Trophic cascades in a formerly cod-dominated ecosystem. Science 308:1621-1623

Heath MR (2005) Changes in the structure and function of the North Sea fish foodweb, 1973-2000, and the impacts of fishing and climate. ICES J Mar Sci 62:847-868

Hop H, Gjøsæter J, Danielssen DS (1992) Seasonal feeding ecology of cod (Gadus morhua L.) on the Norwegian Skagerrak coast. ICES J Mar Sci 49:453-461

ICES (International Council for the Exploration of the Sea) (2006) Report of the ICES Advisory Committee on Fishery Management, Advisory Committee on the Marine Environment and Advisory Committee on Ecosystems. Book 6: the North Sea. ICES Advice, Books 1-10, Copenhagen

Ingle RW (1980) British crabs. Oxford University Press, Oxford

Intergovernmental Panel on Climate Change WGII (2007) Climate change 2007: impacts, adaptation and vulnerability. Cambridge University Press, Cambridge

> Kirby RR, Beaugrand G (2009) Trophic amplification of climate warming. Proc Biol Sci 276:4095-4103 
Kirby RR, Johns DG, Lindley JA (2006) Fathers in hot water: rising sea temperatures and a Northeastern Atlantic pipefish baby boom. Biol Lett 2:597-600

Kirby RR, Beaugrand G, Lindley JA, Richardson AJ, Edwards M, Reid PC (2007) Climate effects and benthic-pelagic coupling in the North Sea. Mar Ecol Prog Ser 330:31-38

Kirby RR, Beaugrand G, Lindley JA (2008) Climate-induced effects on the merozooplankton and the benthic-pelagic ecology of the North Sea. Limnol Oceanogr 53: 1805-1815

Kirby RR, Beaugrand G, Lindley JA (2009) Synergistic effects of climate and fishing in a marine ecosystem. Ecosystems 12:548-561

Lee AJ, Ramster RW (1981) Atlas of the seas around the British Isles. Fish Res Tech Rep 20. Ministry of Agriculture, Fisheries and Food, Lowestoft

Lilly GR, Parsons DG, Kulka DW (2000) Was the increase in shrimp biomass on the northeast Newfoundland Shelf a consequence of a release in predation pressure from cod. J Northwest Atl Fish Sci 27:45-61

Lindley JA (1987) Continuous plankton records: the geographical distributions and seasonal cycles of decapod crustacean larvae and pelagic post-larvae in the northeastern Atlantic Ocean and the North Sea, 1981-3. J Mar Biol Assoc UK 67:145-167

Lindley JA, Williams R, Hunt HG (1993) Anomalous seasonal cycles of decapod crustacean larvae in an exceptionally warm year. J Exp Mar Biol Ecol 172:47-65

Lindley JA, Williams R, Conway DVP (1994) Variability in dry weight and vertical distributions of decapod larvae in the Irish Sea and North Sea during the spring. Mar Biol 120: 385-395

Moore JJ (1986) Crustacea: Decapoda. The marine fauna of the Cullercoats District Number 21. Rep Dove Mar Lab Ser 3, 34:1-81

Neumann H, Ehrich S, Kröncke I (2008) Effects of cold winters and climate on the temporal variability of an epibenthic community in the German Bight. Clim Res 37:241-251

Neumann H, Ehrich S, Kröncke I (2009a) Variability of epifauna and temperature in the northern North Sea. Mar Biol 156:1817-1826

Editorial responsibility: Tim Sparks, Cambridge, UK
Neumann H, Reiss H, Rakers S, Ehrich S, Kröncke I (2009b) Temporal variability in southern North Sea epifauna communities after the cold winter of 1995/1996. ICES J Mar Sci 66:2233-2243

> Oguz T (2007) Nonlinear response of Black Sea pelagic fish stocks to over-exploitation. Mar Ecol Prog Ser 345:211-228

> Österblom H, Hansson S, Larsson U, Hjerne O, Wulff F, Elmgren R, Folke C (2007) Human-induced trophic cascades and ecological regime shifts in the Baltic Sea. Ecosystems 10:877-889

Palumbi SR, Martin A, Romano S, McMillan WO, Stice L, Grabowski G (1991) The simple fools guide to PCR, version 2. Zoology Department, University of Hawaii, Honolulu, HI

Pauly D, Christensen V, Dalsgaard J, Froese R, Torres F Jr (1998) Fishing down marine food webs. Science 279: $860-863$

Rees CB (1952) Continuous plankton records: the decapod larvae in the North Sea 1947-1949. Hull Bull Mar Ecol 3: $157-184$

Rees CB (1955) Continuous plankton records: the decapod larvae in the North Sea 1950-51. Bull Mar Ecol 4:69-80

Rees HL, Eggleton JD, Rachor E, Vanden Berghe E (2007) Structure and dynamics of the North Sea benthos. ICES Coop Res Rep 288. ICES, Copenhagen

$>$ Reid PC, Edwards M, Hunt HG, Warner AJ (1998) Phytoplankton change in the North Atlantic. Nature 391:546

> Signa G, Cartes JE, Solé M, Serrano A, Sánchez F (2008) Trophic ecology of the swimming crab Polybius henslowii Leach, 1820 in Galician and Cantabrian Seas: influences of natural variability and the Prestige oil spill. Cont Shelf Res 28:2659-2667

> Smith BE, Ligenza TJ, Almeida FP, Link JS (2007) The trophic ecology of Atlantic cod: insights from tri-monthly, localized scales of sampling. J Fish Biol 71:749-762

van der Veer HW, Bergman MJN (1987) Predation by crustaceans on a newly settled 0-group plaice Pleuronectes platessa population in the western Wadden Sea. Mar Ecol Prog Ser 35:203-215

- Worm B, Myers RA (2003) Meta-analysis of cod-shrimp interactions reveals top-down control in oceanic food webs. Ecology 84:162-173

Submitted: May 28, 2010; Accepted: August 5, 2010

Proofs received from author(s): September 9, 2010 